\title{
Muck drawing by inclined two-dimensional flow
}

\author{
Olena Kalinichenko ${ }^{1 *}$, Mykhailo Fedko ${ }^{1}$, Ivan Kushnerov ${ }^{1}$, and Mykhailo Hryshchenko ${ }^{1}$ \\ Kryvyi Rih National University, Department of Underground Mining of Useful Mineral Deposits, \\ 11 Matusevycha St., 50027 Kryvyi Rih, Ukraine
}

\begin{abstract}
The work aims at studying and developing an efficient option of layer-by-layer muck drawing from the "dead area" of the footwall for the account of forming an inclined limiting contact of the muck ore with the unmined ore massif. The paper presents a detailed technical and economic analysis of factors and conditions impacting efficiency of muck drawing from the footwall "dead area". The conducted studies of muck drawing on laboratory models considering a modeling scale enable determining optimal parameters of the layer-by-layer ore breaking and, further on, conduct a layer-by-layer muck drawing from the footwall "dead area" with minimum losses and dilution. The article determines regulations of the broken ore layer width considering possible obtaining of maximum muck values. On the basis of the conducted studies there are suggested optimal options of the technology of layer-by-layer breaking and drawing of the muck when forming an inclined limiting contact of the muck ore with the breakage face. The article proves practicability of breaking by inclined layers with formation of a limiting contact of the muck ore with the breakage face and suggests implementation of layer-by-layer muck drawing by an inclined flow.
\end{abstract}

\section{Introduction}

Rich iron ore deposits have been mined in Kryvyi Rih iron ore basin for over 135 years that has resulted in significant increase of mining depths and rock pressure and deterioration of mining and geological conditions of production. High rock pressure and relatively instable ores have decreased prospects for applying efficient level-and-room systems of mining and systems of ore and enclosing rock level caving.

Considering current conditions of mining deposits, underground mining of rich iron ores at Kryvyi Rih basin is carried out by mostly sublevel mining systems with ore and enclosing rock caving [1 - 3].

Along with current advantages, sublevel systems of caving and enclosing rocks are characterized by rather low ore extraction indicators [4-6]. Despite fundamental studies of muck drawing processes, no cardinal changes are seen in this area. Losses and dilution of muck ore are still high and they are unlikely to decrease with depth.

Muck ore losses in blocks are of various character. Ore losses in a slow-moving, or "dead area" of the footwall of the deposit are one of the major reasons for muck ore losses in a stoping block [7-9]. These losses are caused by insufficient dips of the deposits that

\footnotetext{
* Corresponding author: elenakalinichenko v@mail.ru
} 
may make $35-40^{\circ}$ at such underground mines as "Rodina" of the PJSC "Kryvbaszalizrudkom" or the mine named after Artem of the PJSC "ArcelorMittal Kryvyi Rih". At other underground mines of Kryvyi Rih iron ore basin there are also many ore bodies with dips of up to $50-55^{\circ}$ that add to forming slow-moving "dead area" of muck on the footwall of the ore body [10 - 12].

Thus, study and development of highly efficient options of muck drawing from slowmoving "dead areas" on the footwall of ore bodies with insufficient dip angles are a relevant task in terms of their scientific and practical significance.

Ore losses on the footwall of the ore body are known to depend on mining and geological conditions of the deposit. At Kryvyi Rih basin these losses may reach 30-50\% of all reserves of a block [13-15]. In such conditions, additional draw workings in the footwall rocks are the most efficient steps to decrease the amount of ore that is left within the slow-moving "dead area" of the footwall of the ore body [7, 16]. Sometimes, to decrease ore losses in the "dead area" of the footwall of the ore body, some researchers [17, 18] suggest applying the system of sublevel caving of ore and enclosing rocks with formation of dividing ore pillars.

Drawpoints near the hanging wall are undoubtedly less efficient than those near the footwall. That is why, the authors of [19] suggest their moving to the footwall side, in such a way dividing the sublevel into two approximately equal parts for ore to be further on drawn only through the workings in the footwall.

Chernokur V.P. and other researchers $[16,20,21]$ state that when drawing the muck under caved overlying rocks in thin ore bodies with dips of up to $50-65^{\circ}$, a considerable part of it remains on the footwall, thus forming a "dead area" of slow-moving muck.

To decrease muck losses in the "dead area" of the footwall, some researchers [22 - 25] suggest previous working of a triangular shaped stope followed by backfilling the mined area with waste rocks and further mining the block by caving ore and enclosing rocks.

In [23], it is stated that in mining a panel adjacent to the footwall of the ore body by caving ore and enclosing rocks, up to $30-50 \%$ of ore is lost in the slow-moving area near the footwall. To reduce ore losses in the "dead area" of the footwall, the authors suggest the pilot method of mining reserves of this area longitudinally by a compensation room.

The authors of $[15,18,21,26,27]$ suggest another original solution for mining "potentially lost" muck of the "dead area" of the footwall of the ore body - to form a "pioneer-room" in the footwall of the block.

\section{Methods}

To confirm the mentioned assumptions and determine regularities of drawing muck ore by the inclined two-dimensional flow, a layer-by-layer muck drawing from the "dead area" of the footwall through forming the inclined limiting contact of the muck with the unmined ore massif was studied in the laboratory conditions.

The experiments were carried out at the laboratory of ore drawing at the Department of Underground Mining of Useful Mineral Deposits, Kryvyi Rih National University, on standard static models of drawing which are characteristic of Kryvyi Rih iron ore basin deposits.

The studies were carried out for different mining and geological characteristics of rich iron ore bodies with different dip angles and number of drawn muck layers. Muck drawing was studied on laboratory models considering the modeling scale. Modeling methods based on the theory of similarity enabled conclusions that underlie scientific and practical recommendations on drawing muck when forming an inclined limiting contact of the muck with a breakage face.

The amount of the broken ore left in the "dead area" on the footwall before dilution 
(Fig. 1) is known to be found according to the formula suggested by Academician G.M. Malakhov [7]:

$$
p_{0}=\left(\frac{H}{\operatorname{tg} \lambda}+d\right) \frac{H}{2} s-Q_{e l}^{\prime},
$$

where $H$ is height of the caved ore layer, $\mathrm{m} ; \lambda$ is an orebody dip angle, degrees; $d$ is the diameter of a drawpoint, $\mathrm{m} ; s$ is a distance between drawpoint axes, $\mathrm{m} ; Q_{e l}^{\prime}$ is the volume of the drawing ellipsoid truncated by two planes passing transverse to the strike between two drawpoints, $\mathrm{m}^{3}$.

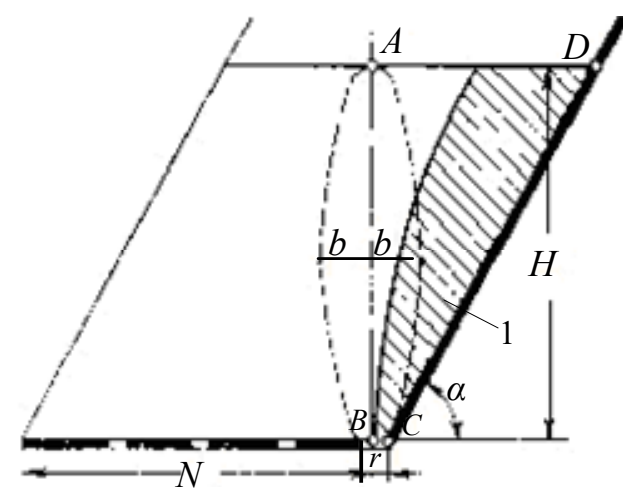

Fig. 1. The diagram for calculating the amount of ore left in the "dead area" on the on the footwall before dilution: 1 the "dead zone" of muck on the footwall of the ore body.

As is seen from the given formula, the volume of muck left on the footwall in the "dead area" of the orebody grows with the increased height of the level (sublevel) and decreased dip of the orebody. Considering the fact that systems of caving ore and enclosed rocks are not currently applied at Kryvyi Rih iron ore basin, the laboratory studies focused on sublevel mining with caving ore and enclosed rocks.

The basic laboratory model for studying ore drawing is given in Fig. 2. The orebody thickness made $25 \mathrm{~m}$, the dip angle in the first series was accepted $50^{\circ}$, the sublevel height made $35 \mathrm{~m}$.

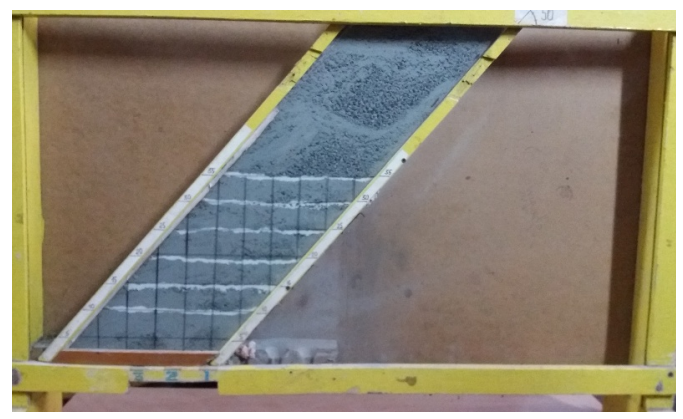

Fig. 2. The laboratory model for studying muck drawing.

\section{Results}

For proper comparison of the results of the laboratory studies, the first series of experiments was conducted according to the classical technology of muck drawing from a range of discharge craters on the main drawing level. 
Physics of modeling results on the intermediate and final stages of drawing is given in Fig. 3.

According to the studies conducted, a significant amount of muck is left on the footwall of the orebody and forms a so-called "dead area", drawing of which from discharge craters on the main level is impossible. The amount of the "dead area" ore on the footwall makes about $45 \%$ for these conditions.

$a$

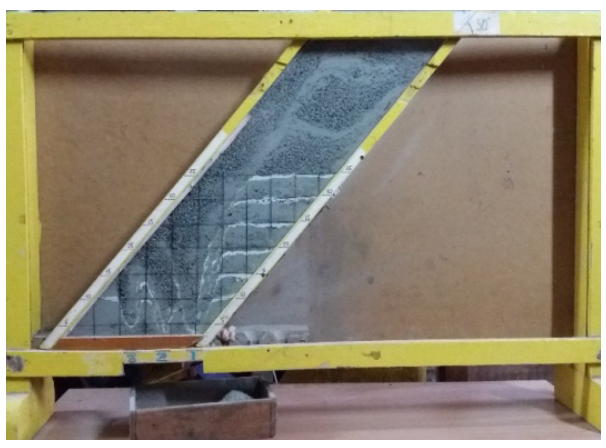

$b$

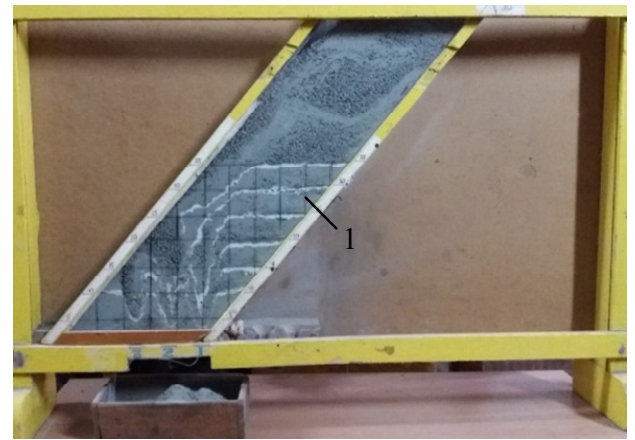

Fig. 3. Physics of modeling results on the intermediate (a) and final (b) stages of drawing according to the classical technology of muck drawing from a range of discharge craters on the main drawing level at the dip angle of $50^{\circ}: 1$ - the "dead area" of muck on the footwall of the ore body.

There are additional steps for further extraction of ore left on the footwall. First of all, this is creating additional sublevel collecting craters and slushing workings in the footwall of the orebody, Fig. 4.

$a$

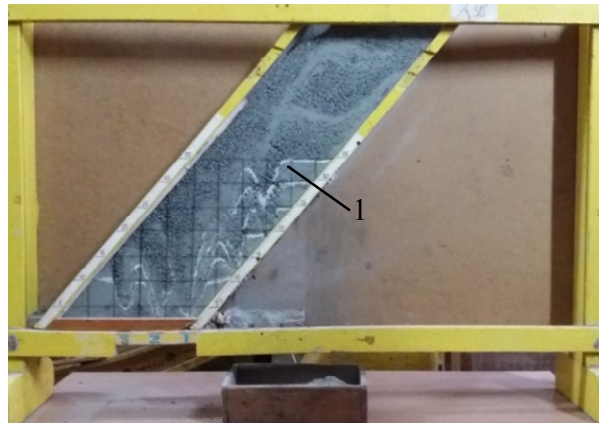

$b$

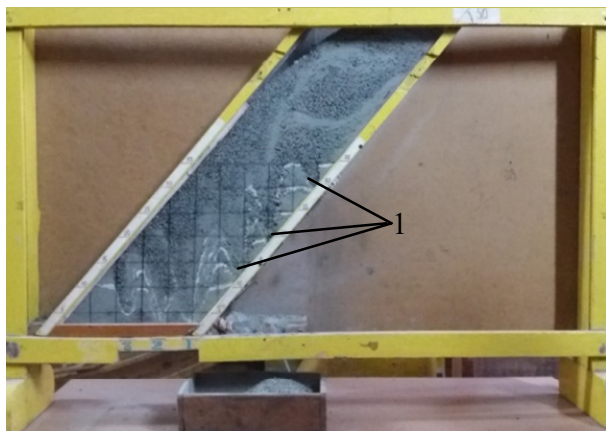

Fig. 4. Physics of modeling results of drawing muck ore from the "dead area" through additional sublevel collecting craters in the footwall on the intermediate (a) and final (b) stages of muck drawing at the orebody dip angle of $50^{\circ}: 1$ - additional sublevel collecting craters in the footwall of the ore body.

This technology is the most common at Kryvyi Rih basin underground mines. At the same time, it is characterized by additional expenses on workings but does not provide complete extraction of ore from the "dead area" of the ore body. Here, ore losses make over $15 \%$ reaching sometimes $20-25 \%$ at insufficient dip angles.

To eliminate the mentioned disadvantages of additional expenses on workings, decrease muck losses, increase extraction indicators and enhance efficiency of the mining system on the whole, we suggest the technology option of layer-by-layer breaking and drawing of 
muck with formation of an inclined limiting contact of the muck with a breakage face as well as a layer-by-layer drawing of muck by the inclined flow.

The angle of forming the inclined muck layer equaled the ore body dip angle.

The point of the suggested technology is in breaking an inclined ore layer onto the whole width of the block. Then, the broken inclined layer is drawn through drawpoints on the main drawing level. The angle of forming the inclined muck layer equaled the ore body dip angle and in the first series it made $50^{\circ}$.

On drawing the inclined ore layer, its place is occupied by overlying waste rocks.

The diagram of drilling and forming an inclined flow of the first layer of muck in the footwall is given in Figs. 5 and 6.
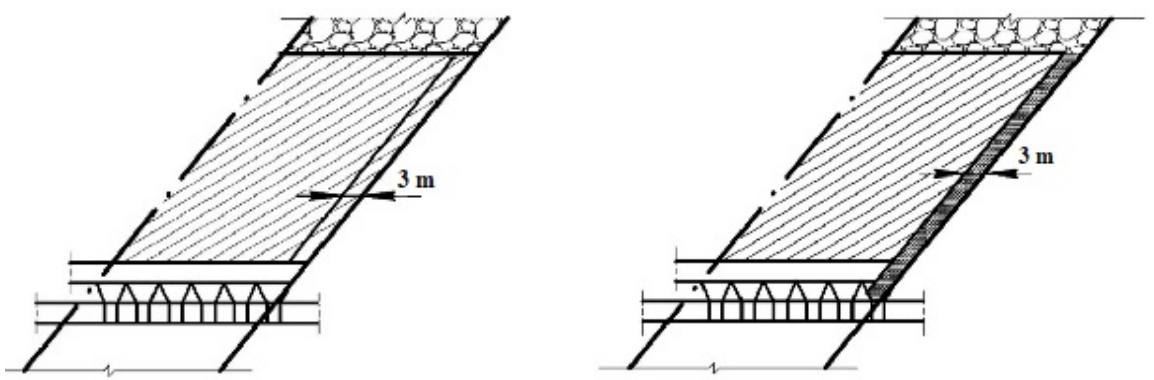

Fig. 5. The diagram of drilling and forming an inclined flow of the first layer of muck.
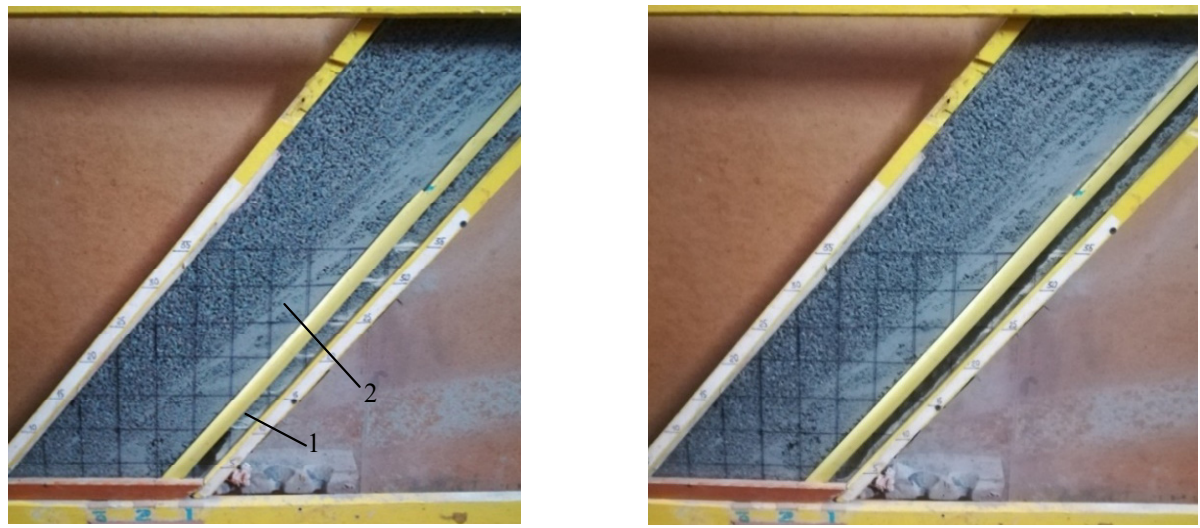

Fig. 6. Stages of drawing an inclined flow of the first layer of muck from the inclined slot under the unmined ore massif at the ore body dip of $50^{\circ}: 1$ - the inclined slot; 2 - the unmined ore massif.

Then the second inclined ore layer is broken on the caved waste rocks. - classical breaking in the "compressed environment" This results in overconsolidated waste rock. Confined environment

Then follows the second muck layer drawing. The results of the study conducted showed the equal width of the drawn and the broken layers.

Next ore layers are broken and drawn similarly until complete mining of the stoping block (panel). Figs. 7 and 8 present stages of the third muck layer drawing.

In this way layer-by-layer breaking and muck drawing is conducted starting from the ore body footwall. Formation of the inclined contact of muck with the unmined massif enables the drawn ore inclined flow parallel to the orebody footwall.

Successive breaking and drawing of ore layers enable extraction of muck practically without losses. Thus, during the study ore losses made $5-7 \%$ in drawing, this being $2.5-3$ 
times less than in muck drawing with formation of additional sublevel collecting craters in the ore body footwall.
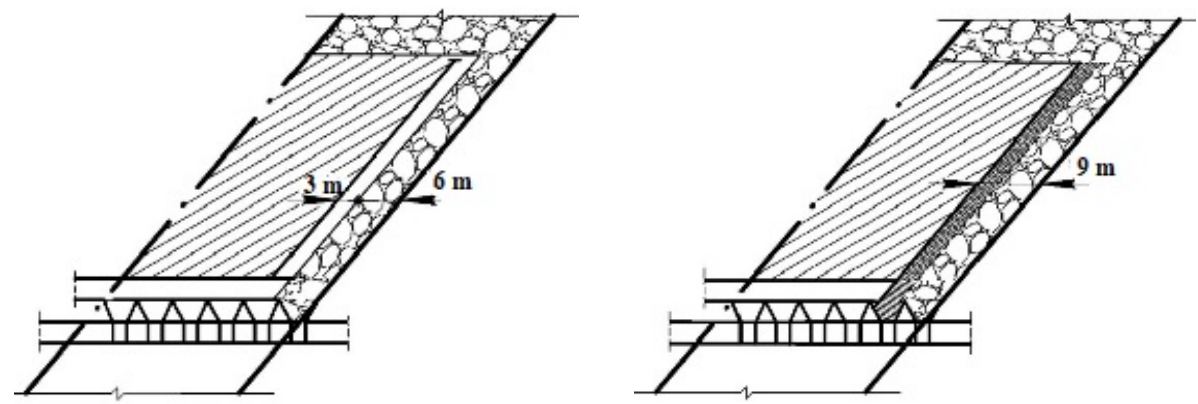

Fig. 7. The diagram of drilling and drawing the inclined flow of the third muck layer along overconsolidated waste rocks.
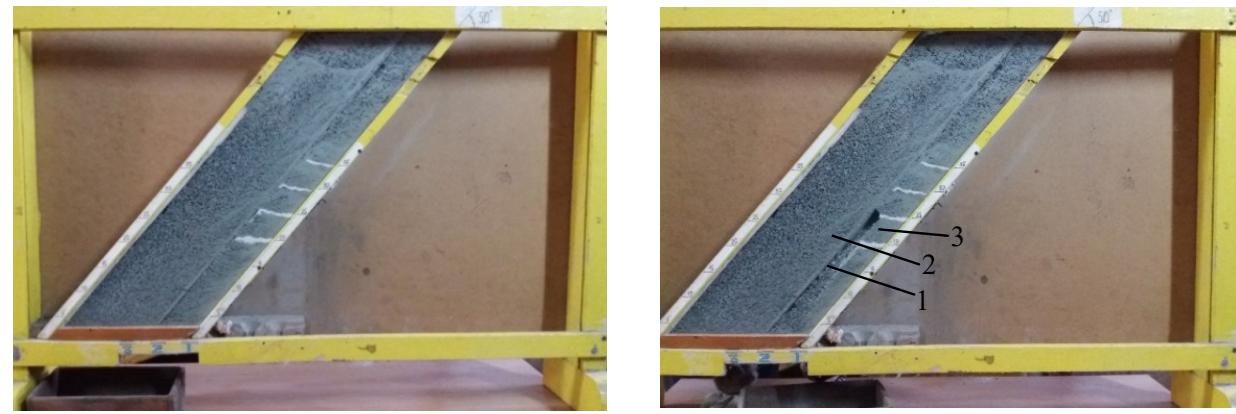

Fig. 8. Stages of the third muck layer drawing along overconsolidated waste rocks under the unmined ore massif at the orebody dip of $50^{\circ}: 1$ - the inclined muck flow; 2 - the unmined ore massif; 3 waste rocks overconsolidated by blasting.

The benefit of this drawing technology is consolidation of waste rocks by blasting in successive breaking of ore layers. The consolidated layer of waste rocks making the surface for drawing the muck, extraction is characterized by absence of dilution by waste rocks.

To confirm the determined regularities, there were conducted laboratory studies of layer-by-layer ore breaking and drawing when forming the inclined limiting contact of the muck with the breakage face at various ore body dips.

Fig. 9 presents stages of drawing the inclined flow of the first muck layer from the inclined slot under the unmined ore massif at the ore body dip of $40^{\circ}$.
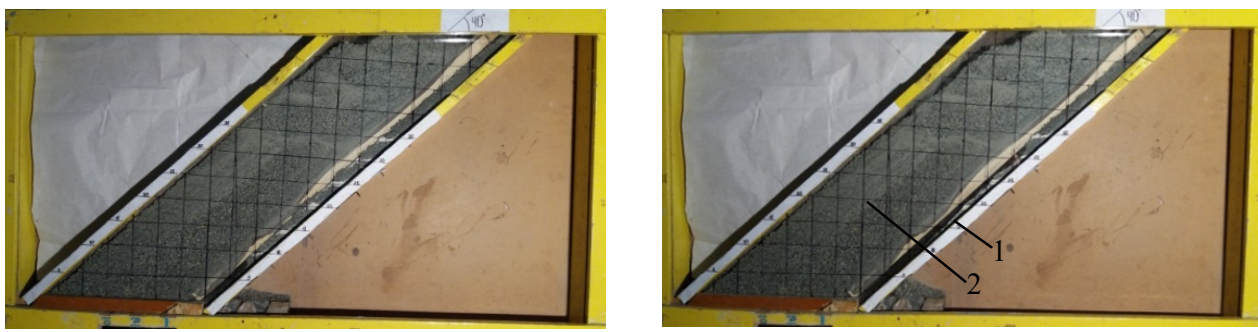

Fig. 9. Stages of drawing the inclined flow of the first muck layer from the inclined slot under the unmined ore massif at the orebody dip of $40^{\circ} .1$ - the inclined muck flow; 2 - the unmined ore massif. 
The modeling results enable the statement that by its nature and the obtained results drawing of the inclined muck flow from the inclined slot under the unmined ore massif at the orebody dip of $40^{\circ}$ does not differ from muck drawing at ore body dip of $50^{\circ}$.

The main requirements during drawing the inclined muck flow from the inclined slot under the unmined ore massif at ore body dips of $50^{\circ}-55^{\circ}$ are the following:

- high quality of the muck;

- no lumps that may cause congestion when drawing the inclined muck flow;

- no inundation of the muck.

\section{Conclusions}

Thus, the paper presents a detailed technical and economic analysis of factors and conditions impacting efficiency of muck drawing from the ore body footwall "dead area". The laboratory studies of muck drawing on stoping block models considering a modeling scale enabled determining the following regularities.

Muck losses in the "dead area" of the ore body footwall depend on the orebody dip and thickness, the stoping block (panel) height and may vary from $25 \%$ to $40 \%$ and sometimes $50 \%$.

Additional collecting craters and slushing workings allow of up to $15-20 \%$ reduction of losses but require considerable expenses.

The authors suggest and prove by the study conducted practicability of the highly efficient technology of layer-by-layer breaking of the ore massif by inclined holes with the subsequent layer-by-layer drawing of the muck. Drawing is performed by the inclined flow along consolidated waste rocks under the inclined contact of the unmined footwall ore massif.

The suggested technology enables increase of muck drawing efficiency without additional expenses on forming collecting workings of the footwall or other steps currently applied at underground mines for extracting reserves of the "dead area" of the ore body footwall.

The laboratory studies showed ore losses during muck drawing of $5-7 \%$ that is practically $2.5-3$ times less than in muck drawing with formation of additional sublevel collecting craters in the ore body footwall.

Besides, the suggested technology enables eliminating additional expenses on additional sublevel collecting craters in the orebody footwall, thus decreasing total mining costs.

The work was supported by the Ministry of Education and Science of Ukraine within the framework of the state scientific topics "Determination of regularities of the stress-strain state of rocks disturbed by workings with the purpose of developing resource-saving ore mining technologies" (State registration No. 0115U003179).

\section{References}

1. Stupnik, M.I. (2016). Development and study of technologies of mining reserves of blocks applying combined ore drawing. Visnyk Kryvorizkoho Natsionalnoho Universytetu, (43), 3-7.

2. Pysmennyi, S., Brovko, D., Shwager,N., Kasatkina, I., Paraniuk, D., \& Serdiuk, O. (2018). Development of complexstructure ore deposits by means of chamber systems under conditions of the Kryvyi Rih iron ore field. Eastern-European Journal of Enterprise Technologies, 5(1(95)), 33-45. https://doi.org/10.15587/1729-4061.2018.142483

3. Stupnik, M., Kolosov, V., Kalinichenko, V., \& Pismennyi, S. (2014). Physical modeling of waste inclusions stability during mining of complex structured deposits. Progressive Technologies of Coal, Coalbed Methane, and Ores Mining, 25-30. https://doi.org/10.1201/b17547 
4. Malanchuk, Z.R. (2019). Substantiating parameters of zeolite-smectite puff-stone washout and migration within an extraction chamber. Naukovyi Visnyk Natsionalnoho Hirnychoho Universytetu, (6). Article in press.

5. Bondarenko, V., Kovalevs'ka, I., Ganushevych, K. (2014). Progressive technologies of coal, coalbed methane, and ores mining. (2014). Progressive Technologies of Coal, Coalbed Methane, and Ores Mining. https://doi.org/10.1201/b17547

6. Malanchuk, Ye., Korniienko, V., Moshynskyi, V., Soroka, V., Khrystyuk, A., \& Malanchuk, Z. (2019). Regularities of hydromechanical amber extraction from sandy deposits. Mining of Mineral Deposits, 13(1), 49-57. https://doi.org/10.33271/mining13.01.049

7. Malakhov, G.M., Besukh, V.R., \& Petrenko, P.D. (1968). Theory and practice of ore drawing. Moskva: Nedra.

8. Golik, V., Komaschenko, V., Morkun, V., \& Khasheva, Z. (2015). The effectiveness of combining the stages of ore fields development. Metallurgical and Mining Industry, (5), 401-405.

9. Dychkovskyi, R.O., Lozynskyi, V.H., Saik, P.B., Petlovanyi, M.V., Malanchuk, Y.Z., \& Malanchuk, Z.R. (2018). Modeling of the disjunctive geological fault influence on the exploitation wells stability during underground coal gasification. Archives of Civil and Mechanical Engineering, 18(4), 1183-1197. https://doi.org/10.1016/j.acme.2018.01.012

10. Kononenko, M., \& Khomenko, O. (2010). Technology of support of workings near to extraction chambers. New Techniques and Technologies in Mining - Proceedings of the School of Underground Mining, 193-197. https://doi.org/10.1201/b11329-32

11. Stupnik, N., Kalinichenko, V., Pismennij, S., \& Kalinichenko, E. (2015). Features of underlying levels opening at "ArsellorMittal Kryvyic Rih" underground mine. New Developments in Mining Engineering 2015: Theoretical and Practical Solutions of Mineral Resources Mining, 39-44. https://doi.org/10.1201/b19901-8

12. Stupnik M.I., Kalinichenko V.O., Kalinichenko O.V., Muzika I.O., Fed'ko M.B., \& Pismennyi S.V. (2015). The research of strain-stress state of magnetite quartzite deposit massif in the condition of mine "Gigant-Gliboka" of central iron ore enrichment works (CGOK). Metallurgical and mining industry, (7), 377-383.

13. Kalinichenko, O.V. (2017). Enhancement of iron ore extraction values in caved ore drawing on the contact with the solidifying artificial massif. Visnyk Kryvorizkoho Natsionalnoho Universytetu, (45), 118-122.

14. Stupnik, M., \& Kalinichenko, O. (2018). Investigation of muck drawing in blocks with trapezoid sills. E3S Web of Conferences, (60), 00021. https://doi.org/10.1051/e3sconf/20186000021

15. Kalinichenko, V.O., \& Kalinichenko, O.V. (2002). The ore body mining method. Patent No. 48630 A, Ukraine.

16. Khomenko, O., Tsendjav, L., Kononenko, M., \& Janchiv, B. (2017). Nuclear-and-fuel power industry of Ukraine: production, science, education. Mining of Mineral Deposits, 11(4), 86-95. https://doi.org/10.15407/mining11.04.086

17. Fedko, M.B., Muzyka, I.O., Pysmennyi, S.V., \& Kalinichenko, O.V. (2019). Determination of drilling and blasting parameters considering the stress-strain state of rock ores. Naukovyi Visnyk Natsionalnoho Hirnychoho Universytetu, (1), 37-41. https://doi.org/10.29202/nvngu/2019-1/20

18. Kalinichenko, V.A., \& Kalinichenko, E.V. (2001). Enhancing efficiency of ore exreaction in systems with caving. Ore deposit mining, (74), 65-68.

19. Kudriavtsev, M.I., Bashtanenko, S.S., \& Zaitsev, I.N. (2005). On increasing efficiency of sublevel ore caving systems. Ore deposit mining, (81), 41-45.

20. Kalinichenko, V.O. (2008). Development of scientific grounds for efficient use of Krivbass raw material base in mining lost ores and magnetite quartzite. PhD Thesis. Kryvyi Rih, Ukraine.

21. Kalinichenko, O., \& Stupnik, M. (2012). Parameters of shear zone and methods of their conditions control at underground mining of steep-dipping iron ore deposits in Kryvyi Rig basin. Geomechanical Processes During Underground Mining - Proceedings of the School of Underground Mining, 15-17. https://doi.org/10.1201/b13157-4

22. Kalinichenko, V., Pysmennyi, S., Shvaher, N., \& Kalinichenko, O. (2018). Selective underground mining of complex structured ore bodies of Kryvyi Rih Iron Ore Basin. E3S Web of Conferences, 
(60), 00041. https://doi.org/10.1051/e3sconf/20186000041

23. Martynov, V.K., \& Kudriavtsev, M.S. (1969). On decrease of losses in the footwall. Moskva: Nedra, 53-57.

24. Stupnik, M.I., Kalinichenko, V.O., Pysmennyi, S.V., \& Kalinichenko, O.V. (2018). Determining the qualitative composition of the equivalent material for simulation of Kryvyi Rih iron ore basin rocks. Naukovyi Visnyk Natsionalnoho Hirnychoho Universytetu, (4), 21-27. https://doi.org/10.29202/nvngu/2018-4/4

25. Kalinichenko, O.V., Stupnik, M.I., Kalinichenko., V.O., \& Chukharev, S.M. (2015). Decrease of costs and ore dilution when mining ore bodies. In International Scientific and Practical Conference (pp. 33-37). Moskva-Budapesht-Vena.

26. Stupnik, N., Kalinichenko, V. \& Pismennyi, S. (2013). Pillars sizing at magnetite quartzites roomwork. Annual Scientific-Technical Collection - Mining of Mineral Deposits 2013, 11-15. http://dx.doi.org/10.1201/b16354-4

27. Stupnik, N., \& Kalinichenko, V. (2013). Magnetite quartzite mining is the future of Kryvyi Rig iron ore basin. Annual Scientific-Technical Collection-Mining of Mineral Deposits 2013, 49-52. https://doi.org/10.1201/b16354-10 